\title{
Analisis Suseptibilitas Magnetik Tanah Pada Lahan Perkebunan Kopi di Kabupaten Solok
}

\author{
Yesi Srihandani Ulfa*, Arif Budiman \\ Laboratorium Fisika Bumi, Jurusan Fisika \\ Fakultas Matematika dan Ilmu Pengetahuan Alam Universitas Andalas \\ Kampus Unand LimauManis, Padang, 25163 Indonesia \\ *yesisrihandaniulfa@gmail.com
}

\begin{abstract}
ABSTRAK
Telah dilakukan analisis suseptibilitas magnetik tanah pada lahan perkebunan kopi di kecamatan Danau Kembar, Kabupaten Solok. Sampel tanah diambil pada dua lokasi yaitu Jorong Aka Gadang (lokasi I) dan Jorong Taluak Kenari (lokasi II). Pada setiap lokasi, sampel diambil pada 10 titik dengan tiga variasi kedalaman, yaitu $20 \mathrm{~cm}, 50 \mathrm{~cm}$, dan $80 \mathrm{~cm}$ sehingga diperoleh 60 sampel. Jarak antar titik pengambilan sampel adalah $2 \mathrm{~m}$. Pengukuran suseptibilitas magnetik menggunakan MS2B Bartington Susceptibility Meter dengan dua frekuensi, yaitu $0,47 \mathrm{kHz}$ low frequency (LF) dan 4,7 kHz high frequency (HF). Pada lokasi I, nilai $\chi_{\mathbf{L F}}$ rata-rata yang diperoleh yaitu $2237,7 \times 10^{-8} \mathrm{~m}^{3} / \mathrm{kg}$, sedangkan nilai $\chi_{\mathbf{H F}}$ rata-rata yaitu $2030,3 \times 10^{-8} \mathrm{~m}^{3} / \mathrm{kg}$. Pada lokasi II, nilai $\chi_{\mathbf{L F}}$ rata-rata yang diperoleh yaitu $1543,7 \times 10^{-8} \mathrm{~m}^{3} / \mathrm{kg}$, sedangkan nilai $\chi_{\mathrm{HF}}$ rata-rata yaitu $1500,2 \times 10^{-8} \mathrm{~m}^{3} / \mathrm{kg}$. Berdasarkan nilai suseptibilitas magnetik, mineral pengontrol bersifat ferimagnetik yaitu hematit $\left(\mathrm{Fe}_{2} \mathrm{O}_{3}\right)$. Nilai suseptibilitas magnetik berbanding lurus dengan konsentrasi Fe dalam tanah dan berbanding terbalik dengan kedalaman pengambilan sampel. Lokasi I memiliki nilai suseptibilitas lebih tinggi daripada lokasi II. Salah satu penyebabnya adalah usia lahan perkebunan pada lokasi I lebih kecil dibandingkan lokasi II. Lahan dengan nilai $\chi_{\mathrm{FD}}(\%)$ kurang dari $2 \%$ masih memiliki kesuburan tanah yang baik untuk bercocok tanam dan tanah dengan nilai $\chi_{\mathrm{FD}}(\%) 2-10 \%$ telah mengalami penurunan kesuburan tanah untuk bercocok tanam.

Kata kunci: suseptibilitas magnetik, kopi, kesuburan tanah
\end{abstract}

\section{ABSTRACT}

An analysis of magnetic susceptibility of soil has been carried out on the land of coffee plantations in Danau Kembar sub-district, Solok Regency. Soil samples were taken at two locations namely Jorong Aka Gadang (location I) and Jorong Taluak Keenari (location II). In each location, samples were taken at 10 points with three depth variations, namely $20 \mathrm{~cm}, 50 \mathrm{~cm}$, and $80 \mathrm{~cm}$ so that 60 samples were obtained. The distance between sample is $2 \mathrm{~m}$. Measurament of magnetic susceptibility using the Bartington Magnetic Susceptibility Meter MS2B with two frequencies, namely $0.47 \mathrm{kHz}$ low frequency (LF) and 4.7 $\mathrm{kHz}$ high frequency $(\mathrm{HF})$. At location I, the average value of $\chi_{L F}$ obtained is $2237,7 \times 10^{-8} \mathrm{~m}^{3} / \mathrm{kg}$, while the value of $\chi_{H F}$ is $2030,3 \times 10^{-8} \mathrm{~m}^{3} / \mathrm{kg}$. At location II, the average value of $\chi_{L F}$ obtained is $1543,7 \times 10^{-8} \mathrm{~m}^{3} / \mathrm{kg}$, while the value of $\chi_{H F}$ is $1500,2 \times 10^{-8} \mathrm{~m}^{3} / \mathrm{kg}$. Based omthe value of magnetic susceptibility, the ferrimagnetic mineral controller is hematit $\left(\mathrm{Fe}_{2} \mathrm{O}_{3}\right)$. The value of of magnetic susceptibility is directly proportional to the depth of sampling. Location I has a higher susceptibility value than location II. It is because of the age of plantation land at location I is smaller than location II. Land with value $\chi_{F D}(\%)$ of less than $2 \%$ still has good soil fertility for farming and soil with a value of $\chi F D(\%) 2-10 \%$ has experienced a decrease in soil fertility for farming

Keywords: magnetic susceptibility, coffee, soil fertility

\section{PENDAHULUAN}

Tanah adalah bagian lapisan kerak bumi yang berperan dalam kehidupan organisme maupun mikroorganisme. Tanah juga diartikan sebagai lapisan permukaan bumi yang paling luar sebagai tempat tumbuhnya tanaman. Tanah mengandung unsur hara yang dapat membantu menyuburkan tanaman. Unsur hara tersebut terbagi menjadi 2 golongan, yaitu makronutrien dan mikronutrien. Makronutrien adalah unsur hara yang dibutuhkan dalam jumlah besar, seperti Nitrogen (N), Fosfor (P), Kalium (K), Kalsium (Ca), Belerang (S), dan Magnesium (Mg), sedangkan mikronutrien adalah unsur hara yang dibutuhkan dalam jumlah sedikit, seperti Besi (Fe), Tembaga (Cu), Seng (Zn), Mangan (Mn), Molibdenum (Mo), Boron (B), dan Klor (Cl). Meskipun dibutuhkan dalam jumlah yang sedikit unsur mikronutrien memiliki peranan penting dalam pertumbuhan tanaman (Syekhfani, 2012).

Unsur Fe sebagai bagian dari unsur mikronutrien memiliki peran penting dalam pertumbuhan tanaman. Fe berperan dalam pembentukan klorofil dan proses fotosintesis. Fe 
akan mengalami perubahan saat kondisi tergenang yaitu mengalami reduksi dari $\mathrm{Fe}^{3+}$ menjadi $\mathrm{Fe}^{2+}$. Perubahan ini sangat menguntungkan bagi tanaman karena besi banyak tersedia dan diserap tanaman dalam bentuk fero $\left(\mathrm{Fe}^{2+}\right)$, namun jika reduksi $\mathrm{Fe}$ berlebih dari kebutuhan tanaman akan menyebabkan keracunan tanaman (Syafruddin, 2011). Fe tidak hanya penting untuk perkembangan dan pertumbuhan tanaman, tetapi juga berpartisipasi dalam mempengaruhi struktur tanah dan kesuburan tanah (Glinski dan Horabik, 2011). Fe merupakan unsur hara yang memiliki sifat magnetik yang paling besar (feromagnetik). Pengidentifikasian kandungan Fe ini dapat dilakukan menggunakan metode spektrometri X-Ray Fluorescence (XRF). XRF merupakan alat yang digunakan untuk menganalisis komposisi kimia beserta konsentrasi unsurunsur yang terkandung dalam suatu sampel. Selain metode XRF, metode suseptibilitas magnetik dapat digunakan untuk menganalisis nilai suseptibilitas mineral magnetik yang terkandung dalam sampel.

Suseptibilitas magnetik adalah sebuah besaran yang menyatakan kerentanan sebuah material terhadap medan magnetik luar $(\mathbf{H})$. Saat medan magnetik luar diberikan, terjadi penyearahan momen magnetik terhadap arah medan magnetik luar yang disebut magnetisasi (M). Besar magnetisasi yang terjadi pada material merupakan total momen magnetik (m) persatuan volum $(V)$, ditunjukan oleh Persamaan 2.1.

$$
\mathbf{M}=\frac{\mathbf{m}}{V}
$$

Penelitian pemanfaatan metode geofisika telah banyak dilakukan dalam bidang pertanian. Haris (2013) melakukan penelitian tentang studi awal perubahan sifat magnetik tanah akibat pemakaian pupuk kimia jenis urea $\left(\left(\mathrm{NH}_{2}\right)_{2} \mathrm{CO}\right)$ di daerah pertanian sekitar Gunung Merapi Kecamatan Sungai Tarab Kabupaten Tanah Datar. Hasil penelitian menunjukkan bahwa nilai suseptibilitas magnetik pada lahan yang sudah dijadikan lahan pertanian lebih rendah dari pada lahan yang belum dijadikan lahan pertanian. Pemakaian pupuk urea ini menyebabkan defisiensi Fe dalam tanah yang disebabkan tingginya penyerapan unsur hara oleh tanaman akibat meningkatnya laju pertumbuhan tanaman. Hikma dkk (2015) telah melakukan penelitian analisis fisika tanah perkebunan apel melalui pengukuran suseptibilitas magnetik dan implikasinya pada produksi apel di dua perkebunan apel yang berbeda. Hasil penelitiannya menunjukkan bahwa perkebunan yang memiliki suseptibilitas yang lebih tinggi memproduksi ukuran buah apel yang lebih besar.

Sumatera Barat merupakan salah satu daerah penghasil kopi di Indonesia. Perkebunan kopi di Sumatera Barat hampir tersebar ke seluruh kabupaten/kota. Salah satu daerah penghasil kopi di Sumatera Barat adalah Kabupaten Solok. Kabupaten Solok merupakan kawasan pegunungan yang memiliki unsur hara yang tergolong tinggi, sehingga pohon kopi dapat tumbuh dengan subur. Penelitian suseptibilitas magnetik tanah perkebunan kopi di Kabupaten Solok, belum pernah dilakukan. Oleh karena itu, dilakukan pengukuran nilai suseptibilitas magnetik dan pengujian kandungan bahan untuk menentukan unsur kimia menggunakan XRF. Penelitian dilakukan pada dua lahan dengan jenis kopi yang sama, namun lokasi yaang berbeda.

\section{METODE}

Pengambilan sampel terdiri dari dua lokasi di Kecamatan danau Kembar, yaitu Lokasi perkebunan kopi yang diambil di dua daerah yaitu Jorong Aka Gadang (lokasi I) pada titik koordinat -1,0582711o LS-100,69688427o BT (Gambar (a)) dan Jorong Taluak Kenari pada titik koordinat -1,0713567o LS- 100,7367724 o BT (Gambar (b)). Pada setiap lahan, sampel diambil pada 10 titik dengan tiga variasi kedalaman, yaitu $20 \mathrm{~cm}, 50 \mathrm{~cm}$, dan $80 \mathrm{~cm}$ sehingga diperoleh 60 sampel. Jarak antar titik pengambilan sampel adalah 2 meter. Sampel diambil menggunakan pipa PVC. Pipa tersebut ditancapkan ke dalam tanah sejauh Tanah yang berada di ujung pipa diambil secukupnya, lalu dimasukkan ke dalam plastik ziplock yang telah diberi tanda. Sampel yang telah diambil dikeringkan pada temperatur kamar selama 24 jam. Pengeringan sampel dilakukan agar uap air yang terkandung pada sampel tanah berkurang. Sampel tanah yang sudah dikeringkan tersebut lalu digerus dan kemudian diayak menggunakan saringan 100 mesh. Sebanyak 8,29 g sampel tanah tersebut dimasukkan ke dalam sample holder. 
Pengukuran suseptibilitas magnetik menggunakan MS2B Bartington Susceptibility Meter dengan dua frekuensi, yaitu $0,465 \mathrm{kHz}$ low frequency (LF) dan $4,65 \mathrm{kHz}$ high frequency (HF). Pengukuran nilai suseptibilitas menggunakan 15 arah pengukuran. Data dari hasil pengukuran dicatat, kemudian diolah menggunakan program Matlab 2015a dan microsoft excel.
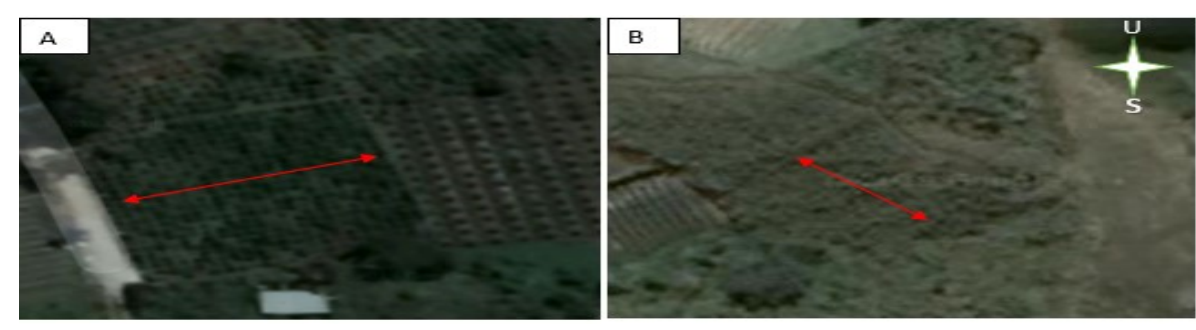

Gambar 1 Lokasi pengambilan sampel. (a) Lokasi I (b) Lokasi II

Pengukuran nilai suseptibilitas magnetik dalam dua frekuensi dimaksudkan untuk memperoleh nilai frequency dependent susceptibility $\chi_{\mathrm{FD}}(\%)$. $\chi_{\mathrm{FD}}(\%)$ merupakan perubahan suseptibilitas dengan frekuensi rendah $\chi_{\mathrm{LF}}$ dan frekuensi tinggi $\chi_{\mathrm{LF}}$ seperti yang ditunjukkan sesuai Persamaan (1).

$$
\chi_{F D} \%=\frac{\left|\chi_{L F}-\chi_{H F}\right|}{\chi_{L F}} \times 100
$$

Nilai $\chi_{\mathrm{FD}}(\%)$ dapat digunakan untuk mengetahui keberadaan bulir superparamagnetik yang terdapat pada sampel. Interpretasi nilai $\chi_{\mathrm{FD}}(\%)$ terhadap keberadaan bulir superparamagnetik dapat dilihat pada Tabel 1.

Tabel 1 Interpretasi nilai $\chi$ FD (\%)

\begin{tabular}{ll}
\hline Nilai $\chi_{\text {FD }}(\mathbf{\%})$ & Keterangan \\
\hline $0,0-2,0$ & Tidak ada atau mengandung kurang dari $10 \%$ bulir superparamagnetic \\
$2,0-10,0$ & $\begin{array}{l}\text { Mengandung bulir superparamagnetik antara } 10 \% \text { sampai dengan } 75 \% \\
\text { yang merupakan campuran antara bulir superparamagnetik yang berukuran } \\
\text { halus dan kasar } \\
\text { Keseluruhan atau mengandung lebih dari } 75 \% \text { bulir superparamagnetic }\end{array}$ \\
\hline $10,0-14,0$ &
\end{tabular}

(Sumber: Dearing, 1999)

Tabel 1 tersebut menunjukkan bahwa semakin tinggi nilai $\chi_{\mathrm{FD}}(\%)$, maka semakin tinggi pula kandungan bulir superparamagnetiknya, namun nilai yang lebih besar dari 14\% adalah sangat jarang dan sering dianggap kesalahan pengukuran (Dearing, 1999).

Penentuan jenis dan konsentrasi mineral yang terkandung pada sampel dilakukan menggunakan uji X-Ray Fluorescence (XRF). Pengujian ini dilakukan terhadap empat sampel untuk mengetahui hubungan kandungan mineral magnetik terhadap nilai suseptibilitas magnetik sampel. Pemilihan keempat sampel berdasarkan nilai $\chi_{\mathrm{LF}}$ tertinggi dan terendah pada masingmasing lokasi.

\section{HASIL DAN DISKUSI}

\subsection{Hubungan Nilai Suseptibilitas dengan Mineral Magnetik Pada Sampel}

Hasil pengolahan data suseptibilitas magnetik sampel yang berasal dari Jorong Aka Gadang (lokasi I) dapat dilihat pada Tabel 2 dan yang berasal dari Jorong Taluak Kenari (lokasi II) dapat dilihat pada Tabel 3 . 
Tabel 2 Hasil pengolahan data suseptibilitas magnetik sampel di dari Jorong Aka Gadang (lokasi I)

\begin{tabular}{|c|c|c|c|c|}
\hline No & $\begin{array}{c}\text { Kode } \\
\text { Sampel }\end{array}$ & $\begin{array}{c}\chi_{\mathrm{LF}} \\
\left(\times 10^{-8} \mathrm{~m}^{3} \mathrm{~kg}^{-1}\right)\end{array}$ & $\underset{\left(\times 10^{-8} \mathrm{~m}^{3} \mathrm{~kg}^{-1}\right)}{\stackrel{\chi_{\mathrm{H}}}{ }}$ & $\chi_{\mathrm{FD}} \%$ \\
\hline 1 & A-01 & 20 & 3187,4 & 3019,5 \\
\hline 2 & A-02 & 20 & 3038,3 & 2857,7 \\
\hline 3 & A-03 & 20 & 3282,5 & 3133,8 \\
\hline 4 & A-04 & 20 & 2960,1 & 2817,0 \\
\hline 5 & A-05 & 20 & 5143,1 & 4845,9 \\
\hline 6 & A-06 & 20 & 4763,5 & 4495,9 \\
\hline 7 & A-07 & 20 & 3187,8 & 3023,6 \\
\hline 8 & A-08 & 20 & 3545,6 & 3373,2 \\
\hline 9 & A-09 & 20 & 3319,5 & 3171,0 \\
\hline 10 & A-10 & 20 & 3177,7 & 3045,4 \\
\hline 11 & B-01 & 50 & 1914,9 & 1849,3 \\
\hline 12 & B-02 & 50 & 2076,2 & 2007,4 \\
\hline 13 & B-03 & 50 & 1883,0 & 1810,3 \\
\hline 14 & B-04 & 50 & 1920,0 & 1849,2 \\
\hline 15 & B-05 & 50 & 1699,0 & 1631,3 \\
\hline 16 & B-06 & 50 & 1792,6 & 1726,6 \\
\hline 17 & B-07 & 50 & 1264,0 & 1220,2 \\
\hline 18 & B-08 & 50 & 1164,7 & 1119,9 \\
\hline 19 & B-09 & 50 & 1615,7 & 1556,8 \\
\hline 20 & B-10 & 50 & 1480,7 & 1436,8 \\
\hline 21 & C-01 & 80 & 1264,0 & 1230,2 \\
\hline 22 & C-02 & 80 & 1164,7 & 1139,9 \\
\hline 23 & C-03 & 80 & 1136.1 & 1110,2 \\
\hline 24 & C-04 & 80 & 1186,5 & 1155,6 \\
\hline 25 & C-05 & 80 & 1095,5 & 1071,6 \\
\hline 26 & C-06 & 80 & 1102,6 & 1071,9 \\
\hline 27 & C-07 & 80 & 1118,2 & 1089,9 \\
\hline 28 & C-08 & 80 & 1068,1 & 1040,7 \\
\hline 29 & C-09 & 80 & 1149,9 & 1120,9 \\
\hline 30 & $C-10$ & 80 & 914,3 & 887,2 \\
\hline
\end{tabular}

Tabel 3 Hasil pengolahan data suseptibilitas magnetik sampel di daerah Jorong Taluak Kenari (lokasi II)

\begin{tabular}{ccccc}
\hline No & $\begin{array}{c}\text { Kode } \\
\text { Sampel }\end{array}$ & $\begin{array}{c}\boldsymbol{\chi}_{\mathbf{L F}} \\
\left(\times \mathbf{1 0}^{-\mathbf{8}} \mathbf{m}^{\mathbf{3}} \mathbf{k g}^{-\mathbf{1}}\right)\end{array}$ & $\begin{array}{c}\boldsymbol{\chi}_{\mathbf{H F}} \\
\left(\times \mathbf{1 0}^{-\mathbf{8}} \mathbf{m}^{\mathbf{3}} \mathbf{k g}^{-\mathbf{1}}\right)\end{array}$ & $\boldsymbol{\chi}_{\mathbf{F D}} \mathbf{\%}$ \\
\hline 1 & D-01 & 20 & 2332,6 & 2254,2 \\
2 & D-02 & 20 & 2210,2 & 2284,2 \\
3 & D-03 & 20 & 2703,8 & 2592,2 \\
4 & D-04 & 20 & 2454,3 & 2355,1 \\
5 & D-05 & 20 & 1814,3 & 1742,9 \\
6 & D-06 & 20 & 1825,7 & 1755,8 \\
7 & D-07 & 20 & 1762,8 & 1690,1 \\
8 & D-08 & 20 & 1771,5 & 1703,9 \\
9 & D-09 & 20 & 2416,7 & 2319,0 \\
10 & D-10 & 20 & 2370,4 & 2280,4 \\
11 & E-01 & 50 & 1620,8 & 1569,1 \\
12 & E-02 & 50 & 1620,1 & 1570,7 \\
13 & E-03 & 50 & 1671,0 & 1623,9 \\
14 & E-04 & 50 & 1593,7 & 1547,8 \\
15 & E-05 & 50 & 1727,4 & 1659,9 \\
16 & E-06 & 50 & 1712,3 & 1656,1 \\
17 & E-07 & 50 & 1503,3 & 1459,6 \\
18 & E-08 & 50 & 1502,0 & 1459,6 \\
19 & E-09 & 50 & 1556,1 & 1518,3 \\
\hline
\end{tabular}




\begin{tabular}{ccccc}
\hline No & $\begin{array}{c}\text { Kode } \\
\text { Sampel }\end{array}$ & $\begin{array}{c}\chi_{\mathbf{L F}} \\
\left(\times \mathbf{1 0}^{-8} \mathbf{m}^{\mathbf{3}} \mathbf{k g}^{-\mathbf{1}}\right)\end{array}$ & $\begin{array}{c}\chi_{\mathbf{H F}} \\
\left(\times \mathbf{1 0}^{-\mathbf{8}} \mathbf{m}^{\mathbf{3}} \mathbf{k g}^{-\mathbf{1}}\right)\end{array}$ & $\boldsymbol{\chi}_{\mathbf{F D}} \mathbf{\%}$ \\
\hline 21 & F-01 & 80 & 706,7 & 693,8 \\
22 & F-02 & 80 & 649,6 & 642,0 \\
23 & F-03 & 80 & 920,8 & 909,1 \\
24 & F-04 & 80 & 912,3 & 896,1 \\
25 & F-05 & 80 & 870,1 & 855,5 \\
26 & F-06 & 80 & 844,4 & 829,6 \\
27 & F-07 & 80 & 924,0 & 910,6 \\
28 & F-08 & 80 & 912,4 & 898,0 \\
29 & F-09 & 80 & 922,0 & 910,1 \\
30 & F-10 & 80 & 957,3 & 938,7 \\
\hline
\end{tabular}

Dari Tabel 2 dapat dilihat bahwa pada lokasi I, nilai $\chi_{\mathbf{L F}}$ rata-rata yang diperoleh yaitu $2237,7 \times 10^{-8} \mathrm{~m}^{3} / \mathrm{kg}$, sedangkan nilai $\chi_{\mathrm{HF}}$ rata-rata yaitu $2030,3 \times 10^{-8} \mathrm{~m}^{3} / \mathrm{kg}$. Dari Tabel 3 juga dapat dilihat bahwa pada lokasi II, nilai $\chi_{\mathbf{L F}}$ rata-rata yang diperoleh yaitu $1543,7 \times 10^{-8} \mathrm{~m}^{3} / \mathrm{kg}$, sedangkan nilai $\chi_{\mathrm{HF}}$ rata-rata yaitu $1500,2 \times 10^{-8} \mathrm{~m}^{3} / \mathrm{kg}$. Berdasarkan nilai-nilai suseptibilitas di atas, diperoleh bahwa sampel-sampel dari kedua lokasi dikontrol oleh mineral magnetik yang bersifat ferimagnetik.

Penentuan jenis dan konsentrasi mineral yang terkandung pada sampel dilakukan menggunakan uji XRF, dapat dilihat di Tabel 4. Pengujian ini dilakukan terhadap empat sampel yang memiliki nilai $\chi_{\mathrm{LF}}$ tertinggi dan terendah pada masing-masing lokasi, yaitu A05 dan C10 untuk lokasi I dan D03 dan F02 untuk lokasi II. Dari Tabel 4 dapat dilihat bahwa keempat sampel memiliki mineral non magnetik lebih dari $85 \%$ yang terdiri dari kuarsa $\left(\mathrm{SiO}_{2}\right)$, magnesium oksida $(\mathrm{MgO})$, aluminium oksida $\left(\mathrm{Al}_{2} \mathrm{O}_{3}\right)$, kalsium oksida $(\mathrm{CaO})$, sedangkan mineral magnetik hanya kurang dari $10 \%$ yaitu hematit $\left(\mathrm{Fe}_{2} \mathrm{O}_{3}\right)$. Jadi, nilai suseptibilitas magnetik pada sampel dikontrol oleh hematit $\left(\mathrm{Fe}_{2} \mathrm{O}_{3}\right)$.

Tabel 4 Jenis dan konsentrasi mineral sampel pada lokasi I dan II

\begin{tabular}{llrrrr}
\hline \multirow{2}{*}{ No } & Mineral & \multicolumn{4}{c}{ Konsentrasi (\%) } \\
\cline { 3 - 5 } & & $\mathbf{A 0 5}$ & $\mathbf{C 1 0}$ & $\mathbf{D 0 3}$ & F02 \\
\hline 1 & $\mathrm{MgO}$ & 0,943 & 0,225 & 1,388 & 1,332 \\
2 & $\mathrm{Al}_{2} \mathrm{O}_{3}$ & 25,472 & 32,021 & 41,773 & 49,71 \\
3 & $\mathrm{SiO}_{2}$ & 53,989 & 51,282 & 39,097 & 36,797 \\
4 & $\mathrm{CaO}$ & 0,771 & 0,502 & 0,278 & 0,392 \\
5 & $\mathrm{Fe}_{2} \mathrm{O}_{3}$ & 15,123 & 9,985 & 13,842 & 8,135 \\
\hline
\end{tabular}

\subsection{Hubungan nilai Suseptibilitas Magnetik dengan Kedalaman}

Tabel 5 Nilai Suseptibilitas lokasi I dan Lokasi II

\begin{tabular}{llrrrr}
\hline No & $\begin{array}{c}\text { Kedalaman } \\
(\mathbf{c m})\end{array}$ & \multicolumn{2}{c}{$\begin{array}{c}\text { Rentang Nilai Suseptibilitas } \\
\left(\times \mathbf{1 0}^{-8} \mathbf{~ m}^{\mathbf{3}} / \mathbf{k g}\right)\end{array}$} & \multicolumn{2}{c}{$\begin{array}{c}\text { Rata-rata } \\
\left(\times \mathbf{1 0}^{-8} \mathbf{m}^{\mathbf{3}} / \mathbf{k g}\right)\end{array}$} \\
\cline { 3 - 6 } & & Lokasi I & \multicolumn{1}{c}{ Lokasi II } & Lokasi I & Lokasi II \\
\hline 1 & 20 & $2960,1-5143,1$ & $1762,8-2703,8$ & 3560,5 & 2166,2 \\
2 & 50 & $1164,7-2076,2$ & $1502,0-1720,4$ & 1681,1 & 1602,8 \\
3 & 80 & $914,3-1264,0$ & $649,6-1712,3$ & 1118,2 & 1011,9 \\
\hline
\end{tabular}

Berdasarkan Tabel 5, terlihat bahwa nilai suseptibilitas magnetik mengalami penurunan seiring dengan bertambahnya nilai kedalaman sampel dari permukaan bumi. Nilai suseptibilitas magnetik rata-rata di lokasi I dan lokasi II pada kedalaman $50 \mathrm{~cm}$ dan $80 \mathrm{~cm}$ memiliki nilai yang relatif sama, sedangkan pada kedalaman $20 \mathrm{~cm}$ nilai suseptibilitas di lokasi I lebih tinggi daripada lokasi II. Pada lokasi I, lahan mulai ditanami kopi sejak 2015-sekarang (4 tahun), sedangkan lokasi II lahan mulai ditanami kopi sejak 2008-sekarang (11 tahun). Usia lahan ini mempengaruhi pertumbuhan akar tanaman dan pemupukan tanaman kopi. Akar pada tanaman kopi berupa akar tunggang. Pada akar tunggang, ada akar-akar kecil yang tumbuh ke samping disebut akar lebar. Pada akar lebar ini terdapat rambut-rambut akar dan tudung akar yang berguna untuk memperluas penyerapan nutrisi bagi tanaman. Semakin lama usia tanaman maka 
pertumbuhan akarnya semakin panjang dan banyak. Akar kopi di lokasi II memiliki akar tunggang yang lebih panjang daripada akar kopi di lokasi I. Penyebaran akar lebarnya pun juga lebih luas sehingga penyerapan unsur-unsur hara di lokasi II lebih tinggi daripada lokasi I sehingga unsur- unsur hara di lokasi II masih berlimpah. Hal ini lah yang menyebabkan nilai suseptibilitas magnetik di lokasi I lebih tinggi daripada lokasi II.

\subsection{Hubungan $\chi_{\mathrm{FD}} \%$ dengan Domain Magnetik}

Tabel 2 dan Tabel 3 berturut-turut menunjukkan bahwa nilai $\chi_{\mathrm{FD}} \%$ yang diperoleh pada lokasi I berkisar antara 2,12-5,95\%, dengan rata rata 3,72\%, sedangkan pada lokasi II berkisar antara $1,17-4,13 \%$, dengan rata-rata $2,80 \%$. Berdasarkan keberadaan bulir susperparamagnetik ini dapat ditentukan ukuran bulir-bulir SP pada sampel. Bulir-bulir SP pada lokasi I lebih bnayak daripada lokasi II. Oleh karena itu, tanah pada lokasi I memiliki tanahnya memiliki butiran halus yang lebih banyak dibandingkan tanah di lokasi II.

Sebaran domain magnetik yang terkandung dalam sampel dapat dilihat dari scattergram seperti yang ditunjukkan pada Gambar 2. Dari scattergram terlihat bahwa semua sampel lokasi I memiliki nilai $\chi_{\mathrm{FD}} \%$ antara $2-10 \%$, sehingga dapat diperkirakan mengandung bulir superparamagnetik antara $10 \%$ sampai dengan $75 \%$ yang merupakan campuran antara bulir superparamagnetik yang berukuran halus dan kasar. Pada lokasi II sebagian besar sampel memiliki nilai $\chi_{\mathrm{FD}} \%$ besar dari $2 \%$, (20 sampel). Hal ini menunjukkan bahwa domain magnetik pada sampel sebagian besar terdiri dari bulir superparamagnetik antara $10 \%$ sampai dengan $75 \%$ yang merupakan campuran antara bulir superparamagnetik yang berukuran halus dan kasar dan beberapa sampel lainnya (10 sampel) terdiri dari bulir Single Domain (SD) dan Multi Domain (MD).
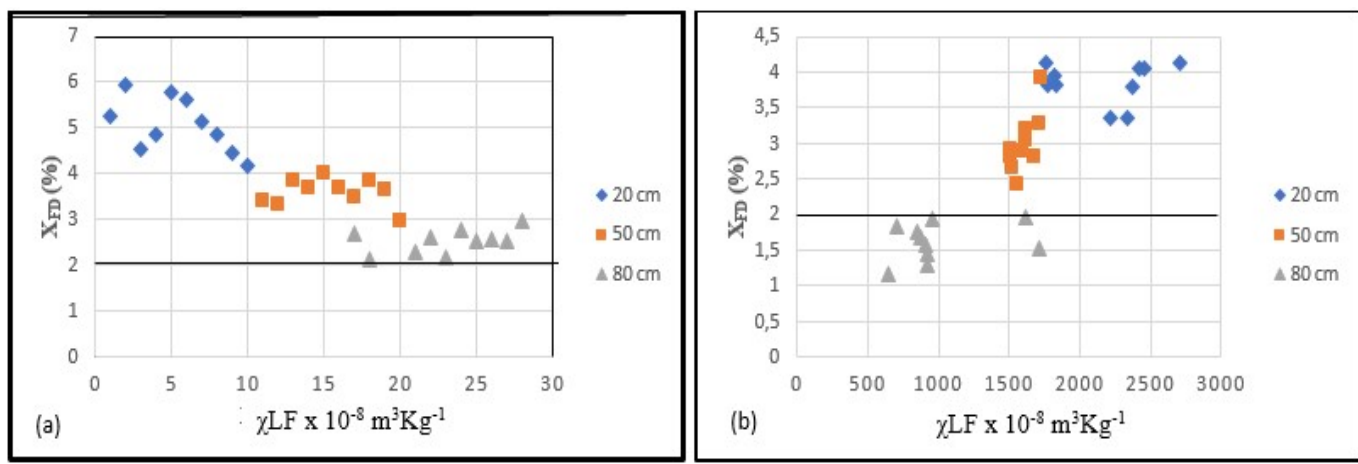

Gambar 2 Grafik hubungan antara nilai suseptibilitas sampel terhadap $\chi_{\mathrm{FD}} \%$ pada (a) lokasi I dan (b) lokasi II

\subsection{Hubungan Nilai Suseptibilitas Magnetik, $\chi_{\mathrm{FD}} \%$, Kandungan Fe dengan Kesuburan tanah}

Tabel 1 Nilai suseptibilitas magnetik dan konsentrasi Fe

\begin{tabular}{ccccc}
\hline No & Kode Sampel & $\begin{array}{c}\boldsymbol{\chi}_{\mathbf{L F}} \\
\left(\times \mathbf{1 0}^{-\mathbf{8}} \mathbf{~ m}^{\mathbf{3}} \mathbf{k g}^{-\mathbf{1}}\right)\end{array}$ & $\begin{array}{c}\text { Konsentrasi Fe } \\
\mathbf{( \% )}\end{array}$ & $\begin{array}{c}\text { Konsentrasi Fe } \\
\mathbf{( p p m )}\end{array}$ \\
\hline 1 & A05 & 5143,0 & 25,001 & 250.010 \\
2 & C10 & 914,3 & 14,894 & 148.940 \\
3 & D03 & 2703,8 & 23,410 & 234.100 \\
4 & F02 & 649,6 & 17,495 & 174.950 \\
\hline
\end{tabular}

Pada Tabel 6, terlihat bahwa secara keseluruhan, urutan konsentrasi Fe dari tinggi ke rendah adalah A05, D03, C10, dan F02. Hal ini sesuai dengan urutan suseptibilitas magnetik yaitu A05, D03, C10, dan F02. Semakin tinggi nilai suseptibilitas magnetik maka semakin tinggi pula konsentrasi Fe. Tanah pada kedua lokasi penelitian ini termasuk tanah dalam kondisi stabil atau tidak terganggu. Mengel dan Kirby (1987), kadar normal kandungan Fe berkisar antara $10.000 \mathrm{ppm}$ sampai $100.000 \mathrm{ppm}$ dalam tanah. Berdasarkan Tabel 6 dapat dilihat bahwa nilai konsentrasi $\mathrm{Fe}(\mathrm{ppm})$ yang diperoleh melebihi kadar normal pada semua sampel. 
Kandungan Fe pada setiap lahan berbeda-beda meskipun lahan berdekatan. Kandungan Fe pada lahan perkebunan kopi daerah I lebih tinggi dibandingkan daerah II. Hal ini disebabkan oleh usia lahan I relatif lebih muda dari lahan II sehingga penyerapan Fe oleh tanaman pada lahan perkebunan kopi daerah I lebih tinggi dibandingkan daerah II. Fe dalam tanah diserap secara difusi oleh akar tanaman dimana dalam hal ini tanah yang mengandung Fe berlaku sebagai daerah berkonsentrasi tinggi dan akar permukaan tanaman berlaku sebagai daerah berkonsentrasi rendah sehingga $\mathrm{Fe}$ akan bergerak menuju permukaan akar tanaman dengan dibantu oleh larutan tanah (Friyandito, 2017). Setiap tanaman membutuhkan kadar Fe yang berbeda-beda sehingga membuat banyaknya pemberian pupuk berbeda-beda pula. Pemberian pupuk kimia menyebabkan kadar Fe dalam tanah berkurang yang disebabkan oleh tingginya penyerapan $\mathrm{N}$ dan $\mathrm{P}$ sehingga mendorong berkurangnya kadar $\mathrm{Fe}$ dalam tanah (Ayu, 2009). Berdasarkan tempat pengambilan sampel, tanah memiliki kandungan $\mathrm{Fe}$ yang berlebih dikhawatirkan tanaman menyerap $\mathrm{Fe}$ terlalu banyak yang menyebabkan terhambatnya penyerapan unsur hara yang lainnya. Oleh karena itu diperlukan pemberian pupuk urea guna menyediakan unsur makro seperti N, P, K agar tanaman menyerap unsur hara yang seimbang.

Keberadaan bulir superparamagnetik pada tanah mengindikasikan bahwa keseluruhan tanah memiliki butiran yang halus. Semakin banyak bulir superparamagnetik yang terkandung dalam tanah, semakin banyak butiran halus yang dimiliki oleh tanah tersebut (Pratiwi, 2016). Berdasarkan nilai $\chi_{\mathrm{FD}} \%$, sampel lokasi I memiliki bulir superparamagnetik lebih banyak dibandingkan sampel lokasi II. Oleh karena itu, dapat dikatakan bahwa sampel lokasi I memiliki butiran yang lebih halus. Lokasi II memiliki bulir yang sedikit, sehingga air hujan langsung masuk kedalaman tanah. Air hujan tersebut dapat menurunkan tingkat kelekatan butiran tanah, sehingga menyebabkan butiran tanah menjadi lebih halus.

Tanah yang memiliki butiran halus lebih mudah menyerap air dibandingkan dengan tanah yang memiliki butiran yang kasar. Hal ini dikarenakan tanah yang lebih halus memiliki luas permukaan yang lebih besar. Air yang terserap ke dalam tanah akan terakumulasi di atas bidang gelincir, sehingga dapat menyebabkan terbawanya unsur-unsur hara yang lain. Oleh karena itu, bisa dikatakan tanah lokasi II dengan nilai $\chi_{\mathrm{FD}}(\%)$ kurang dari $2 \%$ masih memiliki kesuburan tanah yang baik untuk bercocok tanam dan tanah dengan nilai $\chi_{\mathrm{FD}}(\%) 2-10 \%$ telah mengalami penurunan kesuburan tanah untuk bercocok tanam.

\section{KESIMPULAN}

Nilai suseptibilitas magnetik berbanding lurus dengan konsentrasi Fe dalam tanah dan berbanding terbalik dengan kedalaman pengambilan sampel. Lokasi I memiliki nilai suseptibilitas lebih tinggi daripada lokasi II. Salah satu penyebabnya adalah usia lahan perkebunan pada lokasi I lebih kecil dibandingkan lokasi II. Lokasi I memiliki kandungan Fe yang berlebih, sehingga diperlukan pemberian pupuk kimia guna menyediakan unsur hara yang seimbang. Keberadaan bulir superparamagnetik dapat menentukan ukuran bulir SP dari kedua lahan. Oleh karena itu, bisa dikatakan tanah dengan nilai $\chi_{\mathrm{FD}}(\%)$ kurang dari $2 \%$ masih memiliki kesuburan tanah yang baik untuk bercocok tanam dan tanah dengan nilai $\chi_{\mathrm{FD}}(\%) 2-$ $10 \%$ telah mengalami penurunan kesuburan tanah untuk bercocok tanam.

\section{DAFTAR PUSTAKA}

Ayu, L.K., Pengaruh Pemberian Pupuk Urea dan Dolomit Terhadap Perubahan pH Tanah, Serapan N dan P serta Pertumbuhan Tanaman Jagung (Zea Mays) pada Ultisol, Skripsi, Universitas Sumatera Utara, 2009.

Dearing, J., Environmental Magnetic Suseptibility Using the Bartington MS2 System, Chi Publishing, England, 1999.

Glinski, J. dan Horabik, J., Encyclopedia of Agrophysics, Netherlands, Spinger, 2011.

Haris, V., Studi Awal Perubahan Sifat Magnetik Tanah Akibat Pemakaian Pupuk Kimia, Jurnal Sainstek, 5, 2, 97-102, 2013.

Hikma, R., Zulaikah, S., Budi, E., Analisis Sifat Tanah Perkebunan Apel Melalui Pengukuran Suseptibilitas Magnetik, XRF, dan GPR dan Implikasinya Pada Produksi Apel, Universitas Negeri Malang, Malang, 2015. 
Mengel, K., dan Kirby E.A., Principle of Plant Nutrition $4^{\text {th }}$ Edition, International Potash Institute, Zug, Switzerland, 1987.

Pratiwi, R. A., Prakoso, A. G., Darmasetiawan, R., Agustine, E., Kirana, K. H., Fitriani, D., Identifikasi Sifat Magnetik Tanah di Daerah Tanah Longsor, Prosiding Seminar Nasional Fisika (E-journal) SNF2016, 5, 1, 182-187, 2016.

Syafruddin, Keracunan Besi Pada Tanaman Padi dan Pengelolaannya Pada Lahan Sawah, cefars: Jurnal Agribisnis dan Pengembangan Wilayah, 3, 1, 2011.

Syekhfani, Arti Penting Bahan Organik Bagi Kesuburan Tanah, Kongres I dan Semiloka Nasional, 1-8, 2012

Friyandito, Mekanisme Serapan Hara Oleh Tanaman, https://bestplanterindonesia.com/mekanisme-serapan-hara-oleh-tanaman/, 2017 (diakses April 2019). 